\title{
Expression of VEGF 165 b, VEGFR1, VEGFR2 and CD34 in benign and malignant tumors of parotid glands
}

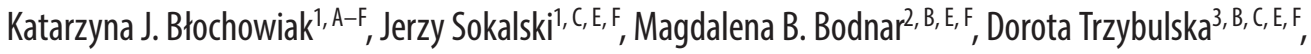 \\ Andrzej K. Marszałek ${ }^{4, B, E, F}$, Henryk Witmanowski ${ }^{5, C, E, F}$ \\ ${ }^{1}$ Department of Oral Surgery, Poznan University of Medical Sciences, Poland \\ ${ }^{2}$ Department of Clinical Pathomorphology, Nicolaus Copernicus University, Collegium Medicum in Bydgoszcz, Poland \\ ${ }^{3}$ Department of Rheumatology and Clinical Immunology, Poznan University of Medical Sciences, Poland \\ ${ }^{4}$ Department of Pathomorphology, Nicolaus Copernicus University, Collegium Medicum in Bydgoszcz, Poland \\ ${ }^{5}$ Department of Physiology, Poznan University of Medical Sciences, Poland \\ A - research concept and design; $\mathrm{B}$ - collection and/or assembly of data; $\mathrm{C}$ - data analysis and interpretation; \\ $D$ - writing the article; $E$ - critical revision of the article; $F$ - final approval of the article
}

Address for correspondence

Katarzyna Błochowiak

E-mail: kasia@naszdentysta.com.pl

\section{Funding sources}

This study was supported by grant

№. 502-14-02212331-09591

(Poznan University of Medical Sciences).

Conflict of interest

None declared

Received on May 25, 2016

Reviewed on June 18,2016

Accepted on August 29, 2016

DOI

10.17219/acem/64876

\section{Copyright}

Copyright by Author(s)

This is an article distributed under the terms of the

Creative Commons Attribution Non-Commercial License

(http://creativecommons.org/licenses/by-nc-nd/4.0/)

\begin{abstract}
Background. Vascular endothelial growth factor (VEGF) is an angiogenic factor and could be involved in the pathogenesis of salivary gland tumors. VEGF exerts its biological function by binding to its receptors, VEGFR1 and VEGFR2. An alternative splice variant of VEGF (VEGFxxxb) is an anti-angiogenic factor. Binding $V_{E G F}$ 165 with VEGFR2 results in an impaired angiogenic response. The imbalance of VEGFXxx and VEGFxxxb isoforms can underpin pathological angiogenesis.
\end{abstract}

Objectives. The purpose of this study was to evaluate and compare the expression of VEGF $165 \mathrm{~b}, \mathrm{VEGFR1}$, VEGFR2, and CD34 in benign and malignant parotid gland tumors and to explore the possible correlations between their expression and clinicopathological features of tumors.

Material and methods. The study was performed on archived paraffin-embedded tissue samples derived from 70 patients with benign and malignant parotid gland tumors (25 with malignant tumors, 23 with pleomorphic adenoma and 22 with Warthin's tumor). Immunohistochemical staining of selected tissue sections was performed using monoclonal antibodies. Immunohistochemical staining of selected molecules was used for evaluation of their expression in tissue sections.

Results. There were no statistically significant differences in the expression of the selected proteins localized in the tumor and surgical margin taken from the same patient. Expression of VEGFR2 correlated with VEGF $165 \mathrm{D}$ in mixed tumors. There was a statistically significant difference in the expression of VEGFR1 in malignant tumors between females and males, and between the expression of VEGFR1 and the score of $T$ classification in malignant tumors.

Conclusions. VEGF 165 cannot be treated as a prognostic factor. VEGF receptors correlated with selected clinicopathological data of malignant tumors, indicating their possible role as a prognostic marker. The balance of VEGF isoforms have a limited influence on the development of parotid glands tumors. The correlation between VEGF 165 and VEGFR2 in mixed tumors suggests the existence of an additional antiangiogenic pathway in poorly vascularized mixed tumors.

Key words: VEGF, angiogenesis, salivary gland tumors, CD34, Warthin's tumor 


\section{Introduction}

Malignant salivary gland tumors are highly invasive and frequently result in distant metastasis. The ability of cancer cells to invade stroma and then to metastasize to both the regional lymph nodes and distant tissue is a complex, multistage process. Tumor growth is regulated by the intensity of angiogenesis. Moreover, newly formed vessels have an impact on the ability of tumor cells to form metastases. Specific angiogenic molecules produced by tumor cells stimulate the surrounding capillary endothelial cells resulting in angiogenesis into tumor tissues. Of these, the vascular endothelial growth factor (VEGF) is the most potent factor in the neovascularization of several neoplasms of salivary glands, especially adenoid cystic carcinomas (ACC) and mucoepidermoid carcinomas. ${ }^{1-6}$ VEGF is a selective mitogen for vascular endothelial cells, which promotes angiogenesis and induces vascular permeability and therefore its inhibition could be integrated into treatment strategies. ${ }^{3}$ Several studies have evaluated whether VEGF immunohistochemical expression may be a prognostic factor for salivary gland carcinomas, but the results are conflicting or inconclusive. In our opinion, the possible source of these conflicting results may be the antagonistic antiangiogenic and proangiogenic properties of VEGF.

VEGF belongs to the platelet-derived growth factor (PDGF) superfamily and consists of glycoproteins with different structures and functions. It functions as a general tumor proangiogenic factor, but there are also different isoforms of VEGF with antiangiogenic properties. Two families of VEGF proteins are formed by an alternative splice-acceptor-site to give to 2 distinctive C-terminal sequences differing in their angiogenic properties. VEGF exerts its biological function by binding to its receptors: VEGFR1, VEGFR2 and VEGFR3. These 2 isoforms bind to VEGFR2 with the same affinity, but the binding of $V_{E G F}{ }_{165} \mathrm{~b}$ results in an insufficient activation of VEGFR2 and an impaired angiogenic response. The imbalance of $\mathrm{VEGF}_{165}$ (proangiogenic) and $\mathrm{VEGF}_{165} \mathrm{~b}$ (antiangiogenic) isoforms can underpin pathological angiogenesis. Primarily, the influence of $\mathrm{VEGF}_{165}$ and $\mathrm{VEGF}_{165} \mathrm{~b}$ on the cancerogenesis of colorectal, renal and breast cancers has been examined. ${ }^{7-13}$ The imbalance of VEGF isoforms in the pathogenesis of salivary gland tumors has not yet been examined.

Another very important issue is the distribution of these isoforms and their receptors in intratumoral and peritumoral tissues. Their different distribution in tumor and stromal cells may have a crucial role for tumor invasiveness. ${ }^{7}$ Although angiogenesis is difficult to measure directly in human tumors, there is increasing evidence that MVD may be an indirect marker of angiogenesis. One of the most common antibodies used for microvessel staining is CD34, which has been used in immunohistochemical studies to evaluate the intra- and peritumoral changes induced by VEGF. ${ }^{14,15}$ Despite the progress made in recent years in understanding the role of VEGF in salivary gland tumors, more data is needed to better elucidate the relationship between the expression of VEGF isoforms and tumor prognosis. To address this need, we determined the prognostic potential of these markers.

The purpose of this study was to evaluate and compare the immunohistochemical expression of $\mathrm{VEGF}_{165} \mathrm{~b}$, VEGFR1, VEGFR2, and CD34 in benign and malignant parotid gland tumors and in surgical margins from the same patients taken as a control group, and to explore the possible correlations between expression of these peptides and the clinicopathological features of tumors.

\section{Material and methods}

\section{Study group}

The study was performed on archived paraffin-embedded tissue samples derived from 70 patients with benign and malignant parotid gland tumors (25 with malignant tumor, 23 with pleomorphic adenoma, and 22 with Warthin's tumor), which were collected in the Department of Oncologic Pathology, Poznan University of Medical Sciences and in the Department of Pathomorphology, Collegium Medicum in Bydgoszcz, Nicolaus Copernicus University in Torun, after surgical treatment of the primary tumor. Exclusion criteria included the presence of lymphoma, previous parotid gland surgery, and other parotid gland pathologies. Clinical examinations included ultrasound and, in selected cases, computed tomography (CT) or magnetic resonance imaging (MRI) to confirm the diagnosis. All tumors were described by location and size. Additionally, malignant tumors were evaluated for stage ( $7^{\text {th }}$ edition of the American Joint Committee on Cancer TNM staging), level of differentiation, regional lymph node metastasis status, and grade. ${ }^{16}$ Tumor diagnosis was performed by pre- and postoperative histopathological examinations. The tumor diagnosis was performed independently by 2 pathologists. Disease-free tumor resection margins, located at least $2 \mathrm{~cm}$ from the tumor, were used as controls.

The protocol for this study was approved by the Bioethics Committee of Poznan University of Medical Sciences, Poland (No. 744/11). All patients provided signed written informed consent.

\section{Tissue microarray paraffin blocks}

Tissue microarray paraffin blocks (TMA) paraffin blocks were prepared for the evaluation of selected protein expression in the same location in the primary tissue sections. The primary paraffin embedded tissue sections (donor blocks) were re-embedded into paraffin-wax tissue blocks. Two tissue cylinders ( $2 \mathrm{~mm}$ in diameter) from each 
case were selected from the "donor blocks", punched from marked regions, and subsequently placed into the recipient TMA blocks using 3DHISTECH TMA Master v. 1.14 (3DHISTECH Ltd, Budapest, Hungary).

\section{Immunohistochemistry}

The paraffin blocks were cut into $4 \mu \mathrm{m}$ tissue sections using a rotary microtome (Accu-Cut ${ }^{\circledR}$ SMRTM200, Sakura, Japan). To establish immunohistochemical procedures, a series of positive control reactions were performed by determining the presence of antigens (The Human Protein Atlas). ${ }^{17}$ The negative control reactions were performed on additional tissue sections during proper immunohistochemical staining, by substituting the primary antibody for a solution of $1 \%$ bovine serum albumin (BSA) in phosphate-buffered saline. Immunohistochemical staining was performed according to protocols described in detail elsewhere. ${ }^{2}$ Immunohistochemical staining of selected tissue sections was performed using the monoclonal antibodies listed in Table 1. Epitopes were unmasked by Epitope Retrieval Solution high-pH (Dako Denmark A/S, Glostrup, Denmark) and then the slides were incubated overnight $(16 \mathrm{~h})$ with a primary antibody at $4^{\circ} \mathrm{C}$. The antibody complex was detected with EnVisionFlex Anti-Mouse/Rabbit HRP Labeled Polymer (Dako Denmark A/S, Glostrup, Denmark). Antigens were localized according to the presence of a brown reaction product, using DAB as a chromogen. Finally, the sections were counterstained with hematoxylin, dehydrated in increasing grades of ethyl alcohol (80\%, 90\%, 96\%, and 99.8\%) and mounted with Shandon Consul Mount (Thermo Fisher Scientific, Waltham, USA).

The results were analyzed using a light microscope (ECLIPSE E800; Nikon Instruments Europe, Amsterdam, the Netherlands), and the level of expression was estimated using morphometric principles. To assess the level of protein expression, we used the modified Remmele-Stegner scale (Index Remmele-Stegner IRS - immunoreactive score), according to the intensity of expression and the number of cells/tissue area positively expressed in our previous publications. ${ }^{2,18}$ Expression of $\operatorname{VEGF}_{165} \mathrm{~b}$, VEGFR1 and VEGFR2 was localized in the cytoplasm and graded as follows: (-) negative; $(+)$ weak positive staining; $(++)$ moderate positive staining; and $(+++)$ strong positive staining. Expression of CD34 was assessed as a positive ( $>5$ blood vessels in the field of view) or negative ( $<5$ blood vessels in the field of view) staining.

\section{Statistical analysis}

The calculations were carried out with the use of Microsoft Excel 2010 and STATISTICA v. 10 software (StatSoft Inc., Tulsa, USA). The distributions of continuous variables obtained at each step of data processing were evaluated for normality using the Shapiro-Wilk test. The age of each group is expressed as a median with an interquartile range (IQR). Categorical variables resulting from immunohistochemistry are presented in contingency tables and they were tested depending on the number of cases using the $\chi^{2}$ test or two-tailed Fisher's exact test. For paired nominal data, the on-line McNemar's test with continuity correction was used. ${ }^{19}$ Probability value $<0.05$ was considered statistically significant.

\section{Results}

There was a statistically significant difference in the expression of VEGFR1 in malignant tumors between females and males (Table 2). A statistically significant difference in the expression of VEGFR1 and a score of T classification in malignant tumors was found (Table 2). A statistically significant correlation between the expression of $\mathrm{VEGF}_{165} \mathrm{~b}$ and VEGFR2 in pleomorphic adenomas was found (Table 3). There were no statistically significant differences in the expression of the selected proteins localized in the tumor and the surgical margin taken from the same patient (Table 4).

\section{Discussion}

Although it is clear that there is a relationship between the expression of VEGF and the development of salivary gland tumors, the exact nature of these relationships remains to be fully explained. In the present study, we analyzed the tissue expression of VEGF $_{165} \mathrm{~b}$, VEGFR1, VEGFR2, and CD34 in pleomorphic adenomas, Warthin's tumors and malignant tumors of the parotid glands to determine their potential value as prognostic and differentiating markers for these tumors. We also assessed expression of $\operatorname{VEGF}_{165} \mathrm{~b}$, VEGFR1, VEGFR2, and CD34 to check for correlations in tumorous and non-tumorous tissues, finding no difference between expression of these molecules in these different tissues. VEGF receptors correlated with selected

Table 1. Primary antibodies used in immunohistochemistry (IHC)

\begin{tabular}{|l|c|c|c|c|}
\hline \multicolumn{1}{|c|}{ Specificity } & Animal & Type & Clone & Catalog No. \\
\hline VEGF $_{165} \mathrm{~b}$ & mouse & monoclonal & $7 F 17$ & Acris antibodies GmBH, Herford, Germany \\
\hline VEGFR1 & mouse & monoclonal & MM0001-7G96 & Novus Biologicals, Abingdon, UK \\
\hline VEGFR2 & rabbit & monoclonal & SP123 & Acris antibodies GmBH, Herford, Germany \\
\hline CD34 & mouse & monoclonal & QBend/10 & AM2104PU-M \\
\hline
\end{tabular}


clinicopathological data of malignant tumors, indicating their possible role as a prognostic marker of salivary tumors. Taken together, these findings suggest that the balance of proangiogenic and antiangiogenic VEGF isoforms seems to have a limited influence on the development of parotid gland tumors, and therefore further research is required. VEGF $_{165}$ b cannot be treated as a prognostic and differentiating factor. The correlation between $\mathrm{VEGF}_{165} \mathrm{~b}$ and VEGFR2 in mixed tumors suggests the existence of an additional antiangiogenic pathway in poorly vascularized mixed tumors.

There were some reports of correlations between the clinicopathological factors of salivary gland tumors and VEGF. According to Lim et al., increased VEGF expression correlated with lymph node metastasis, clinical stage, perineural invasion, vascular invasion, recurrence, and survival. ${ }^{20}$ Similar results were obtained by LequericaFernández et al., who found a relationship between VEGF expression and neck node disease, clinical stage, survival and local control of the tumor. ${ }^{6}$ In our study, antiangiogenic $\mathrm{VEGF}_{165} \mathrm{~b}$ did not correlate with better prognosis and a less severe clinical stage in malignant tumors. VEGF ${ }_{165} \mathrm{~b}$ expression in intratumoral and peritumoral tissues was insufficient for the inhibition of tumor growth and for its invasiveness, or it was limited by $\mathrm{VEGF}_{165}$ or other undetermined angiogenic factors.

The regulation of VEGF alternative splicing is unknown. VEGF gene expression is transcriptionally regulated by a diversity of factors including hypoxia, growth factors,

Table 2. Clinical characteristics of patients with malignant parotid gland cancers, pleomorphic adenoma and Warthin's tumor, and the association of selected parameters with the distribution of VEGF ${ }_{165}$ b, VEGFR1, VEGFR2 assessed as negative (-) for no or weak intensity of expression $(0$ and 1$)$ and positive $(+)$ for moderate and strong intensity of expression (2 and 3), and CD34 expression assessed as negative (-) or positive (+) by immunohistochemistry

\begin{tabular}{|c|c|c|c|c|c|c|c|c|c|c|c|c|c|}
\hline \multirow{3}{*}{\multicolumn{2}{|c|}{ Parameter, $\mathrm{n}$}} & \multicolumn{12}{|c|}{ Protein } \\
\hline & & \multicolumn{3}{|c|}{ VEGF $_{165} \mathrm{~b}$} & \multicolumn{3}{|c|}{ VEGFR1 } & \multicolumn{3}{|c|}{ VEGFR2 } & \multicolumn{3}{|c|}{ CD34 } \\
\hline & & - & + & $p$-value & - & + & p-value & - & + & $\mathrm{p}$-value & - & + & $p$-value \\
\hline Malignant tumors & $\mathrm{n}=25^{\#}$ & 3 & 22 & - & 21 & 4 & - & 8 & 17 & - & 0 & 25 & - \\
\hline $\begin{array}{l}\text { Age (years), } 66(26)^{*} \\
\leq 60 \\
>60\end{array}$ & $\begin{array}{l}11 \\
14\end{array}$ & $\begin{array}{l}0 \\
3\end{array}$ & $\begin{array}{l}11 \\
11\end{array}$ & $.2300^{a}$ & $\begin{array}{c}9 \\
12\end{array}$ & $\begin{array}{l}2 \\
2\end{array}$ & $1.000^{\mathrm{a}}$ & $\begin{array}{l}5 \\
3\end{array}$ & $\begin{array}{c}6 \\
11\end{array}$ & $.3892^{a}$ & $\begin{array}{l}0 \\
0\end{array}$ & $\begin{array}{l}11 \\
14\end{array}$ & $1.000^{\mathrm{a}}$ \\
\hline $\begin{array}{l}\text { Gender, } n \\
\text { males } \\
\text { females }\end{array}$ & $\begin{array}{c}16 \\
9\end{array}$ & $\begin{array}{l}3 \\
0\end{array}$ & $\begin{array}{c}13 \\
9\end{array}$ & $.2800^{\mathrm{a}}$ & $\begin{array}{c}16 \\
5\end{array}$ & $\begin{array}{l}0 \\
4\end{array}$ & $.0100^{\mathrm{a}}$ & $\begin{array}{l}5 \\
3\end{array}$ & $\begin{array}{l}11 \\
6\end{array}$ & $1.000^{\mathrm{a}}$ & $\begin{array}{l}0 \\
0\end{array}$ & $\begin{array}{c}16 \\
9\end{array}$ & $1.000^{\mathrm{a}}$ \\
\hline $\begin{array}{l}\text { Location, } n \\
\text { left side } \\
\text { right side }\end{array}$ & $\begin{array}{l}10 \\
15\end{array}$ & $\begin{array}{l}1 \\
2\end{array}$ & $\begin{array}{c}9 \\
13\end{array}$ & $1.000^{\mathrm{a}}$ & $\begin{array}{l}10 \\
11\end{array}$ & $\begin{array}{l}0 \\
4\end{array}$ & $.1245^{a}$ & $\begin{array}{l}4 \\
4\end{array}$ & $\begin{array}{c}6 \\
11\end{array}$ & $.6668^{a}$ & $\begin{array}{l}0 \\
0\end{array}$ & $\begin{array}{l}10 \\
15\end{array}$ & $1.000^{\mathrm{a}}$ \\
\hline $\begin{array}{l}\text { Invasion, n } \\
\text { deep/superficial } \\
\text { superficial }\end{array}$ & $\begin{array}{l}12 \\
13\end{array}$ & $\begin{array}{l}2 \\
1\end{array}$ & $\begin{array}{l}10 \\
12\end{array}$ & $.5930^{\mathrm{a}}$ & $\begin{array}{c}12 \\
9\end{array}$ & $\begin{array}{l}0 \\
4\end{array}$ & $.0957^{a}$ & $\begin{array}{l}4 \\
4\end{array}$ & $\begin{array}{l}8 \\
9\end{array}$ & $1.000^{\mathrm{a}}$ & $\begin{array}{l}0 \\
0\end{array}$ & $\begin{array}{l}12 \\
13\end{array}$ & $1.000^{\mathrm{a}}$ \\
\hline $\begin{array}{l}\text { Facial palsy, n } \\
\text { yes } \\
\text { no }\end{array}$ & $\begin{array}{c}4 \\
21\end{array}$ & $\begin{array}{l}1 \\
2\end{array}$ & $\begin{array}{c}3 \\
19\end{array}$ & $.4217^{a}$ & $\begin{array}{c}3 \\
18\end{array}$ & $\begin{array}{l}1 \\
3\end{array}$ & $.5269^{a}$ & $\begin{array}{l}1 \\
7\end{array}$ & $\begin{array}{c}3 \\
14\end{array}$ & $1.000^{\mathrm{a}}$ & $\begin{array}{l}0 \\
0\end{array}$ & $\begin{array}{c}4 \\
21\end{array}$ & $1.000^{\mathrm{a}}$ \\
\hline $\begin{array}{l}\text { Grade, n } \\
\text { G1 } \\
\text { G2 } \\
\text { G3 }\end{array}$ & $\begin{array}{l}4 \\
11 \\
10\end{array}$ & $\begin{array}{l}1 \\
2 \\
0\end{array}$ & $\begin{array}{c}3 \\
9 \\
10\end{array}$ & $-\mathrm{b}$ & $\begin{array}{c}2 \\
10 \\
9\end{array}$ & $\begin{array}{l}2 \\
1 \\
1\end{array}$ & $.1288^{b}$ & $\begin{array}{l}1 \\
2 \\
5\end{array}$ & $\begin{array}{l}3 \\
9 \\
5\end{array}$ & $.2802^{b}$ & $\begin{array}{l}0 \\
0 \\
0\end{array}$ & $\begin{array}{c}4 \\
11 \\
10\end{array}$ & - \\
\hline $\begin{array}{l}\text { T classification, } \mathrm{n} \\
\text { T1 } \\
\text { T2 } \\
\text { T3 } \\
\text { T4 }\end{array}$ & $\begin{array}{l}9 \\
3 \\
9 \\
4\end{array}$ & $\begin{array}{l}1 \\
0 \\
1 \\
1\end{array}$ & $\begin{array}{l}8 \\
3 \\
8 \\
3\end{array}$ & $-b$ & $\begin{array}{l}6 \\
2 \\
9 \\
4\end{array}$ & $\begin{array}{l}3 \\
1 \\
0 \\
0\end{array}$ & $-{ }^{b}$ & $\begin{array}{l}3 \\
0 \\
3 \\
2\end{array}$ & $\begin{array}{l}6 \\
3 \\
6 \\
2\end{array}$ & $-\mathrm{b}$ & $\begin{array}{l}0 \\
0 \\
0 \\
0\end{array}$ & $\begin{array}{l}9 \\
3 \\
9 \\
4\end{array}$ & - \\
\hline $\begin{array}{l}\text { N classification, n } \\
\text { Nx } \\
\text { N0 } \\
\text { N1 } \\
\text { N2 }\end{array}$ & $\begin{array}{c}1 \\
12 \\
5 \\
7\end{array}$ & $\begin{array}{l}0 \\
2 \\
0 \\
1\end{array}$ & $\begin{array}{c}1 \\
10 \\
5 \\
6\end{array}$ & $-b$ & $\begin{array}{l}1 \\
9 \\
5 \\
6\end{array}$ & $\begin{array}{l}0 \\
3 \\
0 \\
1\end{array}$ & $-\mathrm{b}$ & $\begin{array}{l}0 \\
4 \\
2 \\
2\end{array}$ & $\begin{array}{l}1 \\
8 \\
3 \\
5\end{array}$ & $-\mathrm{b}$ & $\begin{array}{l}0 \\
0 \\
0 \\
0\end{array}$ & $\begin{array}{c}1 \\
12 \\
5 \\
7\end{array}$ & - \\
\hline $\begin{array}{l}\text { M classification, } \mathrm{n} \\
\text { M0 } \\
\text { M1 }\end{array}$ & $\begin{array}{c}22 \\
3\end{array}$ & $\begin{array}{l}3 \\
0\end{array}$ & $\begin{array}{c}19 \\
3\end{array}$ & 1.000 & $\begin{array}{c}18 \\
3\end{array}$ & $\begin{array}{l}4 \\
0\end{array}$ & 1.000 & $\begin{array}{l}7 \\
1\end{array}$ & $\begin{array}{c}15 \\
2\end{array}$ & 1.000 & $\begin{array}{l}0 \\
0\end{array}$ & $\begin{array}{c}22 \\
3\end{array}$ & - \\
\hline
\end{tabular}

* median (IQR); ${ }^{C}$. ductale $(n=4)$; adenocarcinoma $(n=4) ; C$. planoepitheliale kera $(n=4) ;$. adenoides cysticum $(n=3) ; C$. mucoepidermale $(n=3) ; C$. myoepithelial $(n=2)$; acinic cell carcinoma $(n=1)$; basal cell carcinoma $(n=1)$; C. glandulae salivare $(n=1)$; C. neuroendocrine $(n=1)$; C. ex pleomorphum $(n=1)$; TNM: $\mathrm{T}$ - size or direct extent of the primary tumor, $\mathrm{N}$ - degree of spread to regional lymph nodes, $\mathrm{M}$ - presence of distant metastasis; ${ }^{\mathrm{a}}$ two-tailed Fisher's exact test; ${ }^{b} x^{2}$ for contingency tables. 
Table 2. Clinical characteristics of patients with malignant parotid gland cancers, pleomorphic adenoma and Warthin's tumor, and the association of selected parameters with the distribution of VEGF 165 , VEGFR1, VEGFR2 assessed as negative (-) for no or weak intensity of expression (0 and 1$)$ and positive (+) for moderate and strong intensity of expression (2 and 3), and CD34 expression assessed as negative (-) or positive (+) by immunohistochemistry (cont.)

\begin{tabular}{|c|c|c|c|c|c|c|c|c|c|c|c|c|c|}
\hline \multirow{3}{*}{\multicolumn{2}{|c|}{ Parameter, $\mathrm{n}$}} & \multicolumn{12}{|c|}{ Protein } \\
\hline & & \multicolumn{3}{|c|}{$\mathrm{VEGF}_{165} \mathrm{~b}$} & \multicolumn{3}{|c|}{ VEGFR1 } & \multicolumn{3}{|c|}{ VEGFR2 } & \multicolumn{3}{|c|}{ CD34 } \\
\hline & & - & + & p-value & - & + & p-value & - & + & $p$-value & - & + & $p$-value \\
\hline Pleomorphic adenoma & $n=23$ & 10 & 13 & - & 20 & 3 & - & 12 & 11 & - & 0 & 23 & - \\
\hline $\begin{array}{l}\text { Age (years), } 44(24)^{*} \\
\leq 60 \\
>60\end{array}$ & $\begin{array}{c}16 \\
7\end{array}$ & $\begin{array}{l}9 \\
1\end{array}$ & $\begin{array}{l}7 \\
6\end{array}$ & .0886 & $\begin{array}{c}14 \\
6\end{array}$ & $\begin{array}{l}2 \\
1\end{array}$ & 1.000 & $\begin{array}{l}9 \\
3\end{array}$ & $\begin{array}{l}7 \\
4\end{array}$ & .6668 & $\begin{array}{l}0 \\
0\end{array}$ & $\begin{array}{c}16 \\
7\end{array}$ & 1.000 \\
\hline $\begin{array}{l}\text { Gender, } \mathrm{n} \\
\text { males } \\
\text { females }\end{array}$ & $\begin{array}{c}8 \\
15\end{array}$ & $\begin{array}{l}5 \\
5\end{array}$ & $\begin{array}{c}3 \\
10\end{array}$ & .2213 & $\begin{array}{c}8 \\
12\end{array}$ & $\begin{array}{l}0 \\
3\end{array}$ & .5257 & $\begin{array}{l}5 \\
7\end{array}$ & $\begin{array}{l}3 \\
8\end{array}$ & .6668 & $\begin{array}{l}0 \\
0\end{array}$ & $\begin{array}{c}8 \\
15\end{array}$ & 1.000 \\
\hline $\begin{array}{l}\text { Location, } \mathrm{n} \\
\text { left side } \\
\text { right side }\end{array}$ & $\begin{array}{c}19 \\
4\end{array}$ & $\begin{array}{l}8 \\
2\end{array}$ & $\begin{array}{c}11 \\
2\end{array}$ & 1.000 & $\begin{array}{c}17 \\
3\end{array}$ & $\begin{array}{l}2 \\
1\end{array}$ & .4529 & $\begin{array}{c}11 \\
1\end{array}$ & $\begin{array}{l}8 \\
3\end{array}$ & .3168 & $\begin{array}{l}0 \\
0\end{array}$ & $\begin{array}{c}19 \\
4\end{array}$ & 1.000 \\
\hline $\begin{array}{l}\text { Invasion, n } \\
\text { deep/superficial } \\
\text { superficial }\end{array}$ & $\begin{array}{c}8 \\
15\end{array}$ & $\begin{array}{l}4 \\
6\end{array}$ & $\begin{array}{l}4 \\
9\end{array}$ & .6850 & $\begin{array}{c}7 \\
13\end{array}$ & $\begin{array}{l}1 \\
2\end{array}$ & 1.000 & $\begin{array}{l}4 \\
8\end{array}$ & $\begin{array}{l}4 \\
7\end{array}$ & 1.000 & $\begin{array}{l}0 \\
0\end{array}$ & $\begin{array}{c}8 \\
15\end{array}$ & 1.000 \\
\hline Warthin's tumor & $n=22$ & 7 & 15 & - & 16 & 6 & - & 6 & 16 & - & 1 & 21 & - \\
\hline $\begin{array}{l}\text { Age (years), } 62(5)^{*} \\
\leq 60 \\
>60\end{array}$ & $\begin{array}{c}8 \\
14\end{array}$ & $\begin{array}{l}2 \\
5\end{array}$ & $\begin{array}{l}6 \\
9\end{array}$ & 1.000 & $\begin{array}{c}6 \\
10\end{array}$ & $\begin{array}{l}2 \\
4\end{array}$ & 1.000 & $\begin{array}{l}1 \\
5\end{array}$ & $\begin{array}{l}7 \\
9\end{array}$ & .3512 & $\begin{array}{l}1 \\
0\end{array}$ & $\begin{array}{c}7 \\
14\end{array}$ & .3636 \\
\hline $\begin{array}{l}\text { Gender } \\
\text { males } \\
\text { females }\end{array}$ & $\begin{array}{c}15 \\
7\end{array}$ & $\begin{array}{l}5 \\
2\end{array}$ & $\begin{array}{c}10 \\
5\end{array}$ & 1.000 & $\begin{array}{c}11 \\
5\end{array}$ & $\begin{array}{l}4 \\
2\end{array}$ & 1.000 & $\begin{array}{l}3 \\
3\end{array}$ & $\begin{array}{c}12 \\
4\end{array}$ & .3341 & $\begin{array}{l}1 \\
0\end{array}$ & $\begin{array}{c}14 \\
7\end{array}$ & 1.000 \\
\hline $\begin{array}{l}\text { Location } \\
\text { left side } \\
\text { right side }\end{array}$ & $\begin{array}{l}12 \\
10\end{array}$ & $\begin{array}{l}3 \\
4\end{array}$ & $\begin{array}{l}9 \\
6\end{array}$ & .6517 & $\begin{array}{l}9 \\
7\end{array}$ & $\begin{array}{l}3 \\
3\end{array}$ & 1.000 & $\begin{array}{l}4 \\
2\end{array}$ & $\begin{array}{l}8 \\
8\end{array}$ & .6462 & $\begin{array}{l}0 \\
1\end{array}$ & $\begin{array}{c}12 \\
9\end{array}$ & .4545 \\
\hline $\begin{array}{l}\text { Invasion } \\
\text { deep/superficial } \\
\text { superficial }\end{array}$ & $\begin{array}{c}3 \\
19\end{array}$ & $\begin{array}{l}1 \\
6\end{array}$ & $\begin{array}{c}2 \\
13\end{array}$ & 1.000 & $\begin{array}{c}2 \\
14 \\
\end{array}$ & $\begin{array}{l}1 \\
5\end{array}$ & 1.000 & $\begin{array}{l}1 \\
5\end{array}$ & $\begin{array}{c}2 \\
14 \\
\end{array}$ & 1.000 & $\begin{array}{l}0 \\
1 \\
\end{array}$ & $\begin{array}{c}3 \\
18 \\
\end{array}$ & 1.000 \\
\hline
\end{tabular}

* median (IQR); $C$. ductale $(n=4)$; adenocarcinoma $(n=4)$; C. planoepitheliale kera $(n=4) ; C$. adenoides cysticum $(n=3) ; C$. mucoepidermale $(n=3) ; C$. myoepithelial $(n=2)$; acinic cell carcinoma $(n=1)$; basal cell carcinoma $(n=1)$; C. glandulae salivare $(n=1)$; C. neuroendocrine $(n=1) ; C$. ex pleomorphum $(n=1) ;$ TNM: $\mathrm{T}$ - size or direct extent of the primary tumor, $\mathrm{N}$ - degree of spread to regional lymph nodes, $\mathrm{M}$ - presence of distant metastasis; ${ }^{a}$ two-tailed Fisher's exact test; ${ }^{b} x^{2}$ for contingency tables.

such as insulin-like growth factor 1 (IGF-1), transforming growth factor $\beta 1$ (TGF- $\beta 1$ ), transforming growth factor $\alpha$ (TGF- $\alpha$ ), oncogenes and tumor suppressor genes. ${ }^{10}$ Ishibashi et al. postulated that hypoxia may be one of the factors inducing angiogenesis in salivary gland carcinomas by producing VEGF. ${ }^{1}$ Distribution of these angiogenic factors in tumorous and non-tumorous tissues varies depending on the type of tissue and the local microenvironment. In our opinion, for a comprehensive assessment of the $\mathrm{VEGF}_{165} \mathrm{~b}$ and $\mathrm{VEGF}_{165}$ relationship and their distribution in tumor tissues, the influence of other possible splicing factors should be considered.

Among the molecules which were determined in our study, VEGFR1 expression correlated with the $\mathrm{T}$ score in malignant tumors. According to Younes et al., AEE788, a dual inhibitor of EGF and VEGF receptor tyrosine kinases, increased tumor and cell apoptosis, and decreased microvessel density, which correlated with a decrease in the incidence of vascular metastasis of salivary adenoid cystic carcinoma. This data showed that both receptors, EGFR and VEGFR, can be molecular targets for therapy of salivary ACC. ${ }^{3}$ In the study by de Faria et al., VEGF and its receptor expression levels discriminated benign and malignant tumors of salivary glands but they cannot be treated as a predictor of metastasis from non-metastasizing tumors. ${ }^{4}$ In our study, VEGFR1 was weakly expressed but correlated with the $\mathrm{T}$ score in malignant tumors. This result may suggest its important influence in tumor growth and invasiveness. VEGFR1 seems to be a more sensitive marker of tumor growth than VEGFR2. Although VEGFR2 was more strongly expressed in our study than VEGFR1, it did not correlate with clinical data for malignant tumors. In our opinion, these positive correlations reflected the increased levels of proangiogenic VEGF isoforms in malignant tumors. Expression of VEGFR2 resulted from both VEGF $_{165}$ and VEGF 165 b activity.

VEGFR1 expression in malignant tumors varied for different genders. This correlation was observed only in malignant tumors. In a previous study by Lim et al., the male gender was connected with shorter survival in salivary gland carcinomas. ${ }^{20}$ Many studies have concentrated on the differences in survival in colon cancers according 
to gender-dependent polymorphism of the VEGF gene. ${ }^{21}$ Similar associations between gender, age and family history - dependent VEGF gene polymorphism and the increased risk of osteosarcoma - were determined in studies by Tie et al. ${ }^{22}$ Patel et al., in contrast, did not observe any demographic and gender predispositions for Warthin's tumor compared to other benign salivary gland tumors. However, in the growth of benign tumors, VEGF and its isoforms seem to play a limited role. ${ }^{23}$ Polymorphisms of VEGF and their receptors in salivary gland tumors have not been yet determined. Previously, only the influence of EGF, its receptor EGFR and their polymorphism in salivary gland carcinomas were explored. EGF and VEGF belong to the same family of growth factors and their functions overlap very often. In our view, a larger-scale study would be needed to explain the relation between gender and angiogenic factors in parotid tumors.

There were no statistically significant differences in the expression of molecules determined in the study and localized in the tumor and surgical margin taken from the same patient. Similar results were obtained by Tayama et al. In this study, VEGF was expressed on similar levels in both tumor and stromal cells. Tumor VEGF expression correlated with an advanced clinical stage, and VEGF expression in stromal cells was increased in the earlier clinical stage. Additionally, a splice variant revealed that tumor VEGF was mainly composed of $\mathrm{VEGF}_{165}$ and that stromal VEGF included both VEGF V. $_{165}$ and $V_{E G F} F_{165} \mathrm{~b}$. The microvessel density tended to be lower in cases with higher $V_{E G F}{ }_{165} \mathrm{~b}$ mRNA levels. ${ }^{7}$ Taken together, we suggest that the $\mathrm{VEGF}_{165} \mathrm{~b} / \mathrm{VEGF}_{165}$ ratio, especially in the surrounding stromal cells, can prove more important for tumor invasiveness or inhibition than the overexpression of these isoforms. Additionally, we did not explain what kinds of cells secrete VEGF ${ }_{165} \mathrm{~b}$ and what factors induce $V_{E G F}{ }_{165}$ b expression. Malignant tumors of the salivary glands vary according to their histological structure and their sensitivity to VEGF-induced angiogenesis. Most studies have concentrated on salivary ACC. For comprehensive assessment of the role of VEGF in parotid gland tumors, a study conducted on a bigger and more homogenous group of malignant tumors is needed.

two-tailed Fisher's exact test; $\mathrm{N}$ - number VEGF ${ }_{165} \mathrm{~b}$, VEGFR1, VEGFR2 assessed as negative (-) for no or weak intensity of expression ( 0 and 1$)$ and positive $(+)$ for moderate and strong intensity of expression (2 and 3), and CD34 expression assessed as negative (-) or positive (+) by immunohistochemistry.

Table 4 . Associations of VEGF 165 b, VEGFR1, VEGFR2, and CD34 expression assessed as weak (-) or strong (+) between the tumor and surgical margins taken as a control in the groups studied

\begin{tabular}{|c|c|c|c|c|c|c|c|c|c|c|c|c|c|c|}
\hline \multirow{3}{*}{. } & 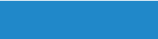 & & \multicolumn{12}{|c|}{ Control } \\
\hline & \multirow{2}{*}{\multicolumn{2}{|c|}{ Parameter }} & \multicolumn{3}{|c|}{ VEGF $_{165} \mathrm{~b}$} & \multicolumn{3}{|c|}{ VEGFR1 } & \multicolumn{3}{|c|}{ VEGFR2 } & \multicolumn{3}{|c|}{ CD34 } \\
\hline & & & + & - & $p^{*}$ & + & - & $\mathrm{p}^{*}$ & + & - & $p^{*}$ & + & - & $\mathrm{p}^{*}$ \\
\hline \multirow{3}{*}{ Tumor } & $\begin{array}{l}\text { malignant } \\
\text { tumor }\end{array}$ & $\begin{array}{l}+ \\
-\end{array}$ & $\begin{array}{l}12 \\
12\end{array}$ & $\begin{array}{l}7 \\
1\end{array}$ & .3588 & $\begin{array}{l}0 \\
3\end{array}$ & $\begin{array}{c}3 \\
16\end{array}$ & .6831 & $\begin{array}{l}8 \\
5\end{array}$ & $\begin{array}{l}3 \\
3\end{array}$ & .7237 & $\begin{array}{c}20 \\
0\end{array}$ & $\begin{array}{l}2 \\
0\end{array}$ & .4795 \\
\hline & $\begin{array}{l}\text { pleomorphic } \\
\text { adenoma* }\end{array}$ & $\begin{array}{l}+ \\
-\end{array}$ & $\begin{array}{l}5 \\
3\end{array}$ & $\begin{array}{l}4 \\
4\end{array}$ & 1.000 & $\begin{array}{l}0 \\
6\end{array}$ & $\begin{array}{c}1 \\
10\end{array}$ & .1306 & $\begin{array}{l}4 \\
7\end{array}$ & $\begin{array}{l}3 \\
2\end{array}$ & .3428 & $\begin{array}{c}15 \\
0\end{array}$ & $\begin{array}{l}2 \\
0\end{array}$ & .4795 \\
\hline & $\begin{array}{l}\text { Warthin's } \\
\text { tumor }\end{array}$ & + & $\begin{array}{l}3 \\
3\end{array}$ & $\begin{array}{l}4 \\
3\end{array}$ & 1.000 & $\begin{array}{l}2 \\
1\end{array}$ & $\begin{array}{l}2 \\
5\end{array}$ & 1.000 & $\begin{array}{l}8 \\
1\end{array}$ & $\begin{array}{l}1 \\
3\end{array}$ & .4795 & $\begin{array}{l}9 \\
1\end{array}$ & $\begin{array}{l}2 \\
0\end{array}$ & 1.000 \\
\hline
\end{tabular}

* McNemar's test with the continuity correction for paired data. 
$(-)$
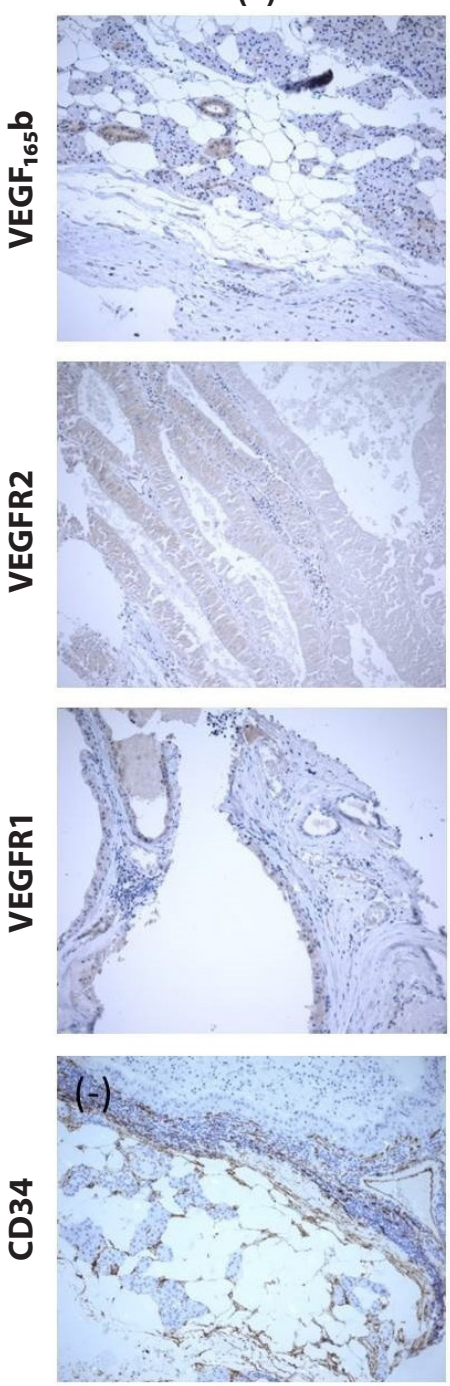

$(+)$
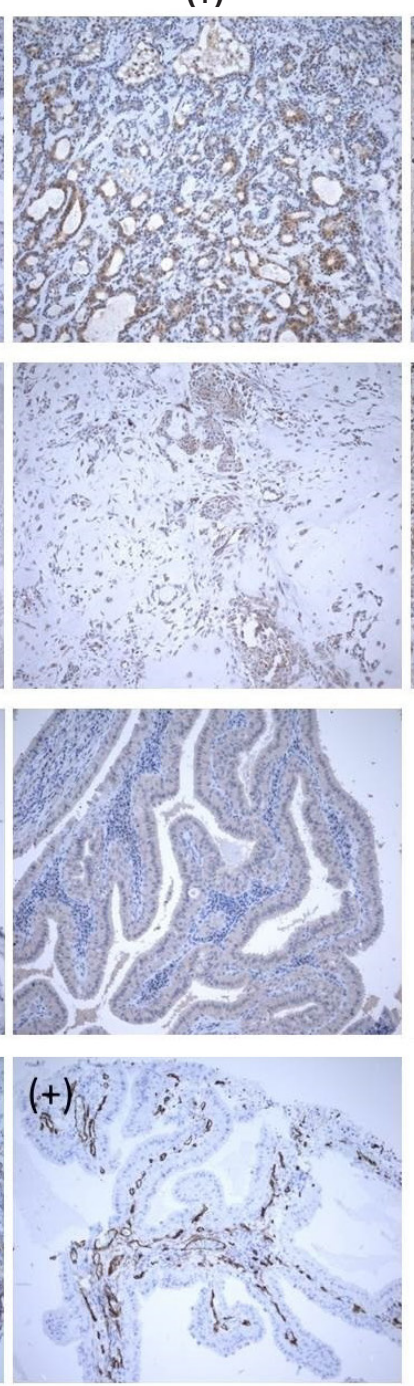
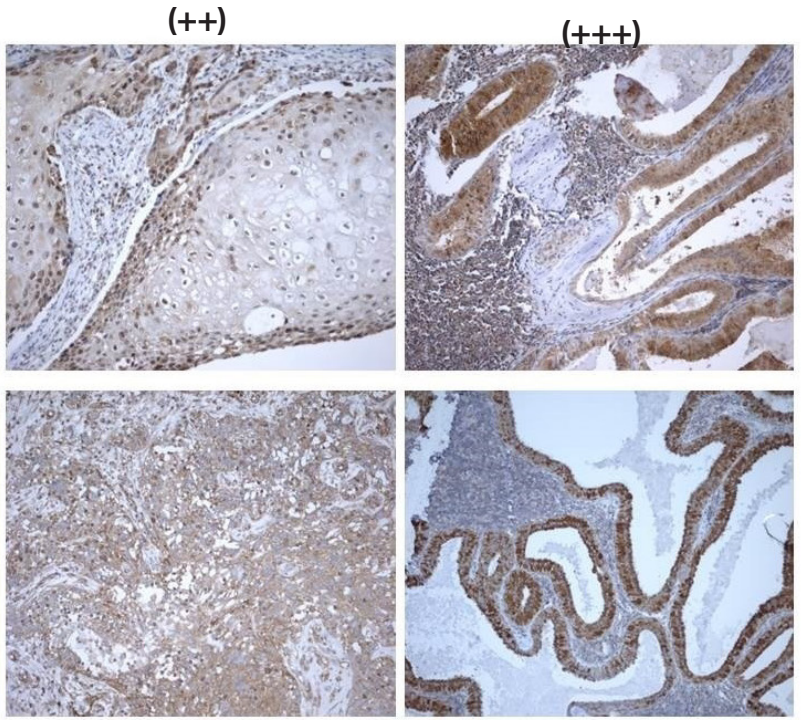

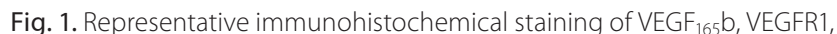
VEGFR2, and CD34. Positive cytoplasmic staining (brown). Nuclei stained with hematoxylin. Primary magnification $\times 10$

In our study, VEGF ${ }_{165}$ b correlated with VEGFR2 in mixed tumors. This is a highly unexpected result, because the stroma of pleomorphic adenoma is always poor in terms of vascularity. This is a contradiction to the general idea of highly vascular neoplasm architectures on which antitumor therapeutic strategies have been devised. On the other hand, in the poorly vascularized tissues of mixed tumors, the hypoxic conditions promote higher VEGF expression. Swelam et al. demonstrated VEGF and its receptors in normal duct epithelial and myoepithelial cells as well as in tumor cells in ductal structures and in myxochondroid stromata. Additionally, they determined at least 4 proangiogenic VEGF isoforms, among which $\mathrm{VEGF}_{121}$ was the most enhanced. They also observed higher HIF-1 $\alpha$ levels in mixed tumors. ${ }^{5}$ These previous results suggested that mixed tumor cells produce VEGF in several functional forms for their own proliferation or differentiation, and that VEGF expression is controlled by the hypoxic circumstances of poorly vascularized mixed tumors. Our results also revealed the existence of an antiangiogenic $V_{E G F}{ }_{165} \mathrm{~b} /$ VEGFR2 pathway in mixed tumors. In our opinion, this

pathway is strictly associated with the special histological structure or special conditions of a mixed tumor. However, we do not explain which mixed tumor cells might be a source of this antiangiogenic mechanism and whether it is primary or secondary to the proangiogenic $\mathrm{VEGF}_{165}$, and which factors can foster its production.

The development of parotid gland tumors is not associated with deterioration in the balance between proangiogenic and antiangiogenic VEGF isoforms. VEGF $_{165} \mathrm{~b}$ levels did not correspond with a less severe clinical stage of parotid gland tumors. Furthermore, this cannot be treated as a prognostic or differentiating factor of malignant and benign parotid gland tumors. Without a comprehensive assessment of the $\mathrm{VEGF}_{165} \mathrm{~b} / \mathrm{VEGF}_{165}$ ratio in tumor and stromal tissues and the influence of their receptors, VEGFR1 and VEGFR2, its expression has limited importance. In our opinion, a more important issue is the ratio of proangiogenic/antiangiogenic VEGF isoforms in the tissue in question. VEGFR1 expression correlated with selected clinicopathological data of malignant tumors, indicating an additional field 
for further research. VEGFR2 correlated with $\mathrm{VEGF}_{165} \mathrm{~b}$ levels in mixed tumors. Its avascularity and complex histological structure with a high proportion of myxoid and chondroid contents seem to have a great affinity with antiangiogenic VEGF isoforms and requires further research.

\section{References}

1. Ishibashi H, Shiratuchi T, Nakagawa K, et al. Hypoxia-induced angiogenesis of cultured human salivary gland carcinoma cells enhances vascular endothelial growth factor production and basic fibroblast growth factor release. Oral Oncol. 2001;37:77-83.

2. Bodnar M, Szylberg $Ł$, Kaźmierczak W, Marszałek A. Differentiated expression of membrane type metalloproteinases (MMP-14, MMP-15) and pro-MMP2 in laryngeal squamous cell carcinoma. A novel mechanism. J Oral Pathol Med. 2013;42:267-274.

3. Younes MN, Park YW, Yazici YD, et al. Concomitant inhibition of epidermal growth factor and vascular endothelial growth factor receptor tyrosine kinases reduces growth and metastasis of human salivary adenoid cystic carcinoma in an orthotopic nude mouse model. Mol Cancer Ther. 2006;5:2696-2705.

4. de Faria PR, Lima RA, Dias FL, et al. Vascular endothelial growth factor and thymidine phosphorylase expression in salivary gland tumors with distinct metastatic behavior. J Oral Pathol Med. 2011;40:456-459.

5. Swelam W, Ida-Yonemochi H, Maruyama S, Ohshiro K, Cheng J, Saku T. Vascular endothelial growth factor in salivary pleomorphic adenomas: One of the reasons for their poorly vascularized stroma. Virchows Arch. 2005;446:653-662.

6. Lequerica-Fernández P, Astudillo A, De Vicente JC. Expression of vascular endothelial growth factor in salivary gland carcinomas correlates with lymph node metastasis. Anti Cancer Res. 2007;27:3661-3666.

7. Tayama M, Furuhata T, Inafuku Y, et al. Vascular endothelial growth factor 165b expression in stromal cells and colorectal cancer. World J Gastroenterol. 2011;17:4867-4874.

8. Dokun AO, Annex BH. The VEGF 165 b "ICE-o-form" puts a chill on the VEGF story. Circ Res. 2011;109:246-247.

9. Qiu Y, Ferguson J, Oltean S, et al. Overexpression of $V_{E G F}{ }_{165} \mathrm{~b}$ in podocytes reduces glomerular permeability. J Am Soc Nephrol. 2010;21:1498-1509.

10. Nowak DG, Woolard J, Amin EM, et al. Expression of pro- and antiangiogenic isoforms of VEGF is differentially regulated by splicing and growth factors. J Cell Science. 2008;121:3487-3495.

11. Rennel ES, Waine E, Guan $\mathrm{H}$, et al. The endogenous anti-angiogenic VEGF isoform, VEGF ${ }_{165} \mathrm{~b}$ inhibits human tumour growth in mice. Br J Cancer. 2008;98:1250-1257.

12. Rennel ES, Hamdollah-Zadeh MA, Wheatley ER, et al. Recombinant human $V_{E G F_{165}}$ b protein is an effective anti-cancer agent in mice. Eur J Cancer. 2008;44:1883-1894.

13. Díaz R, Peña $C$, Silva J, et al. p73 isoforms affect VEGF, VEGF $F_{165}$ b and

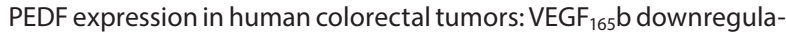
tion as a marker of poor prognosis. Int J Cancer. 2008;123:1060-1067.

14. Kukreja I, Kapoor P, Deshimukh R, Kulkarni V. VEGF and CD34: A correlation between tumor angiogenesis and microvessel density - An immunohistochemical study. J Oral Maxillofac Pathol. 2013;3:367-373.

15. Muhammadnejad S, Muhammadnejad A, Haddadi M, et al. Correlation of microvessel dentistry with nuclear pleomorphic, mitotic count and vascular invasion in breast and prostate cancers at preclinical and clinical levels. Asian Pac J Cancer Prev. 2013;14:63-68.

16. Edge SB, Compton CC. The American Joint Committee on cancer the $7^{\text {th }}$ edition of the AJCC cancer staging manual and future of TNM. Ann Surg Oncol. 2010;17:1471-1474.

17. The Human Protein Atlas. http://www.proteinatlas.org. Accessed January 2 - March 31, 2015.

18. Burduk PK, Bodnar M, Sawicki P, et al. Expression of metalloproteinases 2 and 9 and tissue inhibitors 1 and 2 as predictors of lymph node metastases in oropharyngeal squamous cell carcinoma. Head Neck. 2015;37:418-422.

19. McNemar test calculator - GraphPad. http://www.graphpad.com/ quickcalcs/McNemar1.cfm. Accessed January 2 - March 31, 2015.
20. Lim JJ, Kang S, Lee MR, et al. Expression of vascular endothelial growth factor in salivary gland carcinomas and its relation to $\mathrm{p} 53$, Ki-67 and prognosis. J Oral Pathol Med. 2003;32:552-561.

21. Bae SJ, Kim JW, Kang H, Hwang SG, Oh D, Kim NK. Gender-specific association between polymorphism of vascular endothelial growth factor (VEGF 936C>T) gene and colon cancer in Korea. Anticancer Res. 2008;28(2B):1271-1276.

22. Tie Z, Bai R, Zhai Z, et al. Single nucleotide polymorphisms in VEGF gene are associatted with an increased risk of osteosarcoma. Int J Clin Exp Pathol. 2014;7(11):8143-8149.

23. Patel DK, Morton RP. Demographics of benign parotid tumours: Warthin's tumour versus other benign salivary tumours. Acta Otolaryngol. 2016;136:83-83. 